\title{
DEVETDESET LET GEOGRAFSKE KNJIŽNICE
}

\author{
Martina Frelih, Ida Knez Račič, Lucija Miklič Cvek, Janja Turk \\ Oddelek za geografijo, Filozofska fakulteta Univerze v Ljubljani \\ Aškerčeva 2, SI- I000 Ljubljana \\ e-mail: martina.frelih@ff.uni-lj.si; ida.knez-racic@ff.uni-lj.si; \\ lucija.mikliccvek@ff.uni-lj.si; janja.turk@ff.uni-lj.si
}

Strokovni članek

COBISS 1.04

\section{Izvleček}

Članek predstavlja devetdeset let delovanja knjižnice Oddelka za geografijo, ki je po velikosti fonda druga največja knjižnica na Filozofski fakulteti v Ljubljani in osrednja visokošolska knjižnica za geografijo. Opisani so njen nastanek, prostorske spremembe, razvoj knjižnične zbirke, kader knjižnice in knjižnični katalogi. Pomemben del knjižničnega fonda je kartografsko gradivo, ki se ga hrani v kartografski zbirki. Knjižnica nudi različne storitve - poleg najpomembnejše izposoje knjižničnega gradiva je to izobraževanje uporabnikov, izdelovanje bibliografij, dostop do informacijskih virov in objavljanje Biltena novosti. V sklepnem delu so podani načrti za prihodnost knjižnice.

Ključne besede: Univerza v Ljubljani, Filozofska fakulteta, geografska knjižnica, razvoj knjižnice

\section{NINETY YEARS OF GEOGRAPHICAL LIBRARY}

\begin{abstract}
The article presents the ninety years of activity of the library at the Department of Geography whose holdings rank it as the second biggest library at the Faculty of Arts as well as the main high-school geographical library. Described are its formation, the changes of its location, its employees, the development of the library holdings, and the catalogues. The cartographic material stored in the map room figures an important part of the library holdings. Various services are offered to library's users - borrowing of the library material, training of users, making of bibliographies, access to the information sources, and the publishing of Bilten novosti. The plans for the future are presented in the closing part.
\end{abstract}

Key words: University of Ljubljana, Faculty of Arts, geographical library, development of the library 


\section{UVOD}

V letu 2009 praznujemo devetdesetletnico ustanovitve Filozofske fakultete Univerze v Ljubljani. Jubileju se pridružuje tudi Oddelek za geografijo in njegova knjižnica s kartografsko zbirko, ki je ena izmed najstarejših knjižnic Filozofske fakultete. Od skromnih začetkov do danes se je knjižnica strokovno razvijala in postala osrednja visokošolska knjižnica za geografijo v Sloveniji. Vsa ta leta je v okviru možnosti (prostorskih, kadrovskih in finančnih) izpolnjevala poslanstvo visokošolske knjižnice: nudila podporo študijskemu in raziskovalnemu delu, poučevanju, ustvarjanju novega znanja in prenosu znanja iz bogatih knjižničnih zbirk. Ob tem jubileju želimo predstaviti prehojeno pot in izpostaviti pomembnejše mejnike v njenem razvoju.

\section{UTRINKI IZ PRETEKLOSTI}

Ob ustanovitvi Univerze v Ljubljani je bil na tedanji Filozofski fakulteti predviden tudi študij geografije. Geografski institut je pričel z delom leta 1921. Svoje prostore je imel v drugem nadstropju Deželnega dvorca, v katerem se danes nahaja sedež Univerze v Ljubljani. Geografski institut je deloval v enem večjem in treh manjših prostorih. Njegove skromne začetke je v krajšem članku avtentično opisal Artur Gavazzi (Gavazzi 1922), njegov prvi predstojnik. A. Gavazzi je organiziral tudi geografsko knjižnico, v svojem kabinetu je imel še manjšo zasebno knjižnico. Od tujih geografskih društev, založb ter vladnih ustanov tedanje Jugoslavije je knjižnica prejela v dar 1200 dragocenih geografskih knjig in strokovnih revij.

Knjige, revije in karte so bile shranjene $\mathrm{v}$ vseh prostorih. V veliki seminarski sobi sta bili dve omari za knjige in revije. Karte so bile shranjene kar v dveh predalih miz, ki so ju uporabljali študenti za študij. V eni od sob so med opremo za razvijanje filmov in aparati za kemijske analize vode visele stenske karte. O nabavi knjižnega gradiva je odločal predstojnik instituta. Za knjižnico so skrbeli asistenti, pomagali so jim študenti geografije, ki so jih imenovali dijaški bibliotekarji. V nekaj letih se je knjižnična zbirka povečala in strokovno uredila. V knjižnici je bilo 2424 knjig, 184 periodik, 930 zemljevidov, od tega 33 stenskih. Gradivo je bilo postavljeno po formatu, urejena sta bila abecedni avtorski in strokovni katalog. Knjižnica je bila odprta vsak dan od 9. do 12. in od 16. do 18. ure (Pivec Stele 1933).

Leta 1922 je bilo ustanovljeno Geografsko društvo Slovenije, ki je imelo v prostorih Geografskega instituta svojo posebno knjižnico. Društvena knjižnica je pridobivala gradivo z darovi in zameno Geografskega vestnika za domače in tuje revije (prva številka je izšla 1925).

Šele po drugi svetovni vojni je Geografski institut pridobil dodatne prostore. Gradivo so shranjevali v vseh razpoložljivih prostorih instituta in celo na hodniku. Število knjižničnega gradiva je z leti raslo, povečevalo se je tudi število študentov in s tem uporabnikov geografske knjižnice. Knjižnica je potrebovala bibliotekarja; leta 1954 je dobila asistenta za knjižna dela in leta 1957 prvega poklicnega bibliotekarja.

Leta 1961 je bila zgrajena nova stavba Filozofske fakultete na Aškerčevi cesti. V drugo nadstropje se je preselil Geografski institut, ki se je takrat preimenoval v Oddelek za geografijo. Tudi geografska knjižnica je dobila nove prostore, v katerih se je knjižnična dejavnost 
razvila in razmahnila. Gradivo so postavili na nove knjižne police, preuredili kataloge, separate vložili v škatle in jih presignirali. V študijskem letu 1975/1976 so zamenjali del dotrajanih lesenih omar za karte in jih nadomestili z novimi kovinskimi omarami. Leta 1983 je knjižnica pridobila dvoje novih prostorov in v enem uredila čitalnico za študente. $\mathrm{V}$ osemdesetih letih so bili postavljeni temelji računalniške obdelave knjižničnega gradiva in poslovanja knjižnice.

Slika 1: Knjižnica Oddelka za geografijo (foto: M. Rebolj)

Figure 1: The library of the Department of Geography (photo: M. Rebolj)

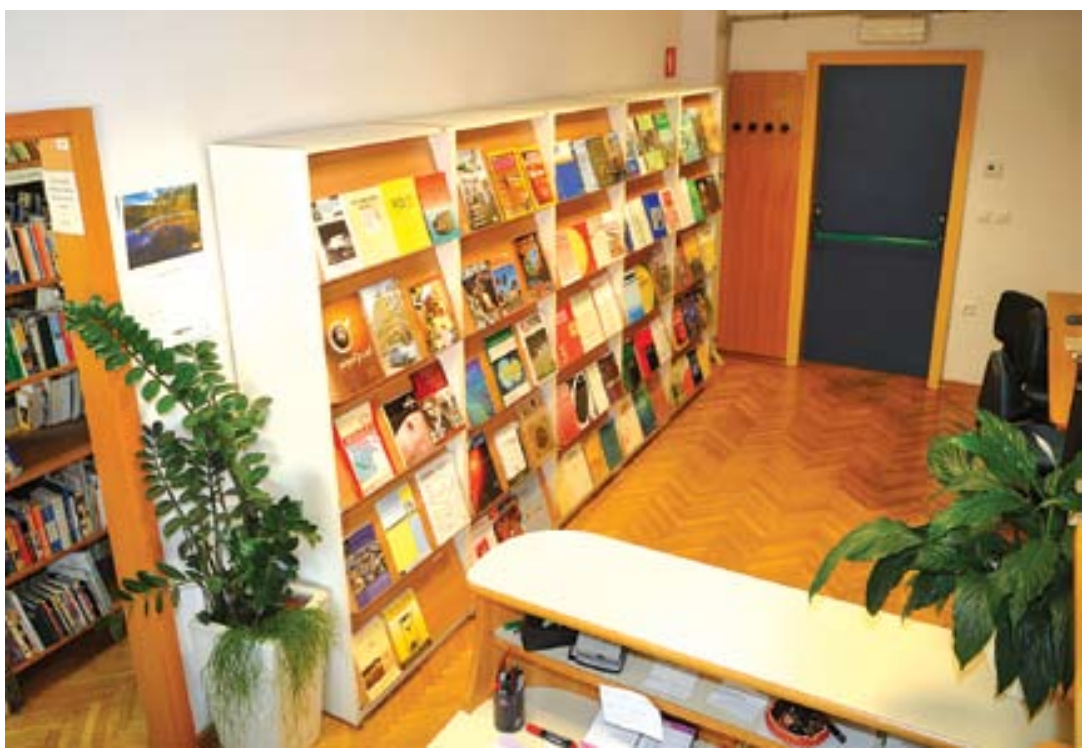

(Vir: Arhiv Knjižnice Oddelka za Geografijo)

Leta 1996 je bila popolnoma obnovljena kartografska zbirka. Opremljena je bila z novimi omarami za atlase in stenske karte. Leto kasneje je doživela prenovo informacijska sprejemna pisarna, postavljene so bile tudi razstavne omare za revije. Obiskovalci so lahko uporabljali dva računalnika za iskanje po računalniških katalogih.

Knjižnična zbirka je naraščala, število študentov geografije je preseglo 500, kar se je pokazalo v povečanem obisku in izposoji knjižničnega gradiva.

Konec devetdesetih let je več deset let star sistem postavitve gradiva po velikosti formata in tekoči številki zamenjala postavitev po področjih geografije z uporabo vrstilcev UDK. Taka postavitev bi omogočala prost pristop do knjižničnega gradiva, a ga prostorske razmere niso dopuščale in še danes preprečujejo vsem uporabnikom knjižnice prost pristop do gradiva.

Leta 1999 se je pričela računalniško vodena izposoja knjižnega gradiva, leto kasneje tudi kartografskega. Knjižnica se je prvič predstavila na domači spletni strani Oddelka za geografijo na medmrežju. Knjižnice Filozofske fakultete so se leta 1996 organizacijsko povezale v Osrednjo humanistično knjižnico Filozofske fakultete (OHK FF). 
Od začetka študijskega leta 2005/2006 je na oddelčni domači strani dostopen Katalog pisnih del, digitalna zbirka diplomskih in magistrskih del ter doktorskih disertacij.

Po več kot štiridesetih letih Filozofske fakultete so se leta 2006 pričele obnove prostorov, stavbnega pohištva in električnih inštalacij ter ureditev prezračevanja. Knjižnica s kartografsko zbirko je bila temeljito prenovljena, izgubili pa smo skoraj 100 metrov polic za knjižno gradivo, ki smo ga morali preseliti v depo OHK FF na Karlovški cesti v Ljubljani. V prenovljenih prostorih smo zaposleni bibliotekarji dobili primerne prostore za delo, študenti nekaj čitalniških mest, knjižno gradivo pa še vedno čaka na nove prostore in uporabnikom prijazen prost pristop do gradiva.

\section{ZAPOSLENI V KNJIŽNICI}

Strokovno dobro urejene knjižnice s primerno knjižnično zbirko in knjižničnimi storitvami si ne moremo predstavljati brez knjižničnih delavcev, bibliotekarjev. Geografski institut in kasneje Oddelek za geografijo sta se tega zavedala in vse od ustanovitve dalje skrbno načrtovala kadrovsko politiko v geografski knjižnici. Prva leta so asistenti in študenti pod strokovnim vodstvom in nadzorom profesorjev z neverjetnim entuziazmom skrbeli za knjižnično gradivo. Šele sredi petdesetih let se je na oddelku zaposlila Tatjana Šifrer kot asistentka za knjižna dela in po opravljenem strokovnem izpitu kot prva poklicna bibliotekarka. $\mathrm{V}$ knjižnici je delovala vse do upokojitve in uspešno združevala svojo strokovno izobrazbo z bibliotekarsko stroko. Znala je prisluhniti potrebam obiskovalcev knjižnice in predvsem zahtevam razvoja geografije in knjižničarstva. Skrbela je za načrtno in sistematično gradnjo knjižnične zbirke, uredila kataloge, katalogizirala ne samo knjige, temveč tudi članke iz domačih in tujih geografskih revij in s tem poskrbela za pretok strokovnih informacij do uporabnikov v času, ko so bili dobro urejeni listkovni katalogi osnovni vir informacij.

Kartografsko zbirko so pred njenim prihodom pomagali urejati: laborant Sokol Vukelj, laborant Pavel Markelj in strokovna sodelavka Jelka Kunaver. Zaradi večanja knjižnične zbirke, števila študentov, izposoje in obiska se je leta 1972 v knjižnici zaposlila Tončka Abbad, ki je prevzela tudi izposojo v prostorsko ločeni kartografski zbirki. Knjižnica se je prilagajala potrebam uporabnikov, širila je informacijsko dejavnost, povečevala se je tudi knjižnična zbirka, pokazale so se potrebe po novih kadrih. Na osnovi preteklega dela se je potrdilo, da knjižnica potrebuje bibliotekarja z geografsko univerzitetno izobrazbo, ki bo lahko svoje geografsko znanje nadgradil s strokovnim bibliotekarskim delom in tako izpolnil pričakovanja uporabnikov ter zahtev matične stroke. Tako se je leta 1979 v knjižnici zaposlila Janja Turk in leta 1987 Mojca Dolgan Petrič. Po upokojitvi Tatjane Šifrer se je leta 1989 v knjižnici zaposlila Ida Knez Račič, po odhodu Mojce Dolgan Petrič pa je na njeno delovno mesto leta 2000 prišla Lucija Miklič Cvek. Po sklepu Oddelka za geografijo od leta 2003 pri knjižničnih opravilih pomaga Simona Lukič.

Leta 2008 se je upokojila Tončka Abbad. Presistematizacija delovnega mesta knjižnični manipulant v delovno mesto bibliotekar je omogočila zaposlitev Martini Frelih.

V knjižnico so bili od začetka dalje vključeni študenti geografije, ki so kot demonstratorji pomagali pri različnih knjižničarskih opravilih. Knjižnica je imela sprva enega demonstratorja, že vrsto let pa demonstratorsko delo v knjižnici in kartografski zbirki opravljata dva 
študenta geografije. Njihova pomoč je bila in je še vedno nepogrešljiva pri zamudnem vlaganju kataložnih listkov v klasične kataloge, preurejanju postavitve knjig in kart, kontroli postavitve gradiva, pošiljanju revij v zameno in drugo.

V obdobju 1999-2001 se je knjižnica vključila v projekt javnih del Ministrstva za delo, družino in socialne zadeve. V tem obdobju so bile za določen čas zaposlene Katarina Hribernik (1999), Simona Deželak (2000) in Damjana Kolar (2000 in 2001).

\section{KNJIŽNIČNA ZBIRKA}

\section{I. O zbirki}

Od prvih začetkov delovanja knjižnice do danes se je knjižnična zbirka povečala od skromnih nekaj sto na 92.504 enot (leto 2008), kar jo uvršča med največje knjižnice Filozofske fakultete, hkrati pa je tudi največja knjižnica za geografijo v Sloveniji. Knjižnično zbirko sestavljajo domača in tuja dela s področja geografije in tudi drugih ved (npr. geologija, biologija, statistika, zgodovina). Gradivo pridobiva z nakupi, darovi, zamenjavo in obveznim izvodom matične fakultete. Letni prirast je bil vsa leta močno odvisen od materialnih sredstev, ki jih dobiva od Ministrstva za visoko šolstvo, znanost in tehnologijo, matične ustanove in lastnih prihodkov iz javne službe (članarine, zamudnine itd.).

Kljub stalnemu pomanjkanju prihodkov za nakup novega knjižnega in neknjižnega gradiva se knjižnična zbirka povečuje. Prirast gradiva se je v primerjavi z letoma 1988 (1060 inventarnih enot) in letom 1998 (1415 inventarnih enot) povečal na 2074 inventarnih enot v letu 2000. Zadnja leta pa beležimo zmanjševanje dotoka novega gradiva; leta 2008 smo inventarizirali 1440 enot knjižničnega gradiva. Tudi struktura prirasta se spreminja. Nakup gradiva predstavlja le še $20 \%$ vsega gradiva (2008). Zamena niha, saj je odvisna od pritoka geografskih revij, in je pomenila leta $200816 \%$ vsega prirasta. V zadnjih letih se odstotek gradiva, pridobljenega $z$ darovi, giblje okoli $39 \%$. Leta 2008 je obvezni izvod, kamor štejemo doktorske disertacije, magistrska, diplomska in seminarska dela ter knjige, izdane na matični ustanovi, predstavljal $25 \%$ celotnega prirasta.

V knjižnici hranimo in katalogiziramo izdelke študentov dodiplomskega študija. V večini so to seminarske naloge in diplomska dela. Vse več je projektnih nalog ali študij, ki jih v okviru študijskih usmeritev pod mentorstvom profesorjev pripravljajo študenti. Posebna zbirka so magistrska dela in doktorske disertacije, ki jih knjižnica prejema kot obvezni izvod matične fakultete. Leta 1988 je zbirka seminarskih nalog, diplomskih in magistrskih del ter doktorskih disertacij štela 2573, leta 2008 pa že 6268 izvodov.

Geografska knjižnica ima bogato zbirko turističnih vodnikov. Zbirka se je posebej obogatila v letih 1997 in 1999, ko je Študentska organizacija Univerze v Ljubljani s Filozofsko fakulteto sklenila pogodbo o medsebojnem poslovnem sodelovanju. S prejetimi sredstvi je geografska knjižnica kupila več kot 1200 turističnih vodnikov in kart. Konec leta 1997 je bila v geografski knjižnici otvoritev 'popotniške zbirke', ki je bila namenjena vsem študentom ljubljanske univerze. Turistični vodniki za posamezne države in mesta Evrope in sveta so postavljeni v prostem pristopu. 
Slika 2: Knjižnična zbirka geografske knjižnice

Figure 2: The holdings of Geographical Library

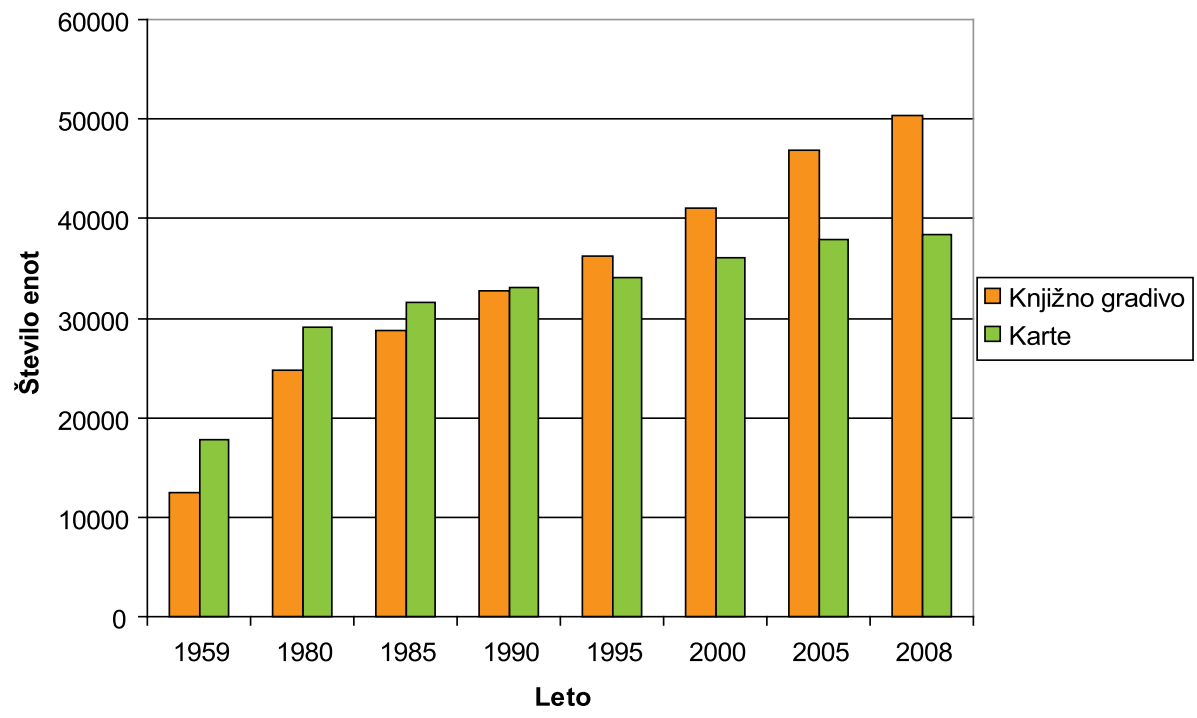

Vir/Source: Poročila o delu visokošolske knjižnice za leta 1959, 1980, 1985, 1990, 1995, 2000, 2005, 2008

Sestavni del knjižnične zbirke je tudi 1112 knjig in 3871 letnikov revij, ki so pripadale knjižnici Geografskega društva Slovenije. Zbirka se je povečevala z darovi in predvsem z zameno domače revije Geografski vestnik $\mathrm{z}$ domačimi in tujimi geografskimi revijami. Knjižnica je rasla do leta 1969, ko je Oddelek za geografijo pričel odkupovati Geografski vestnik od Geografskega društva Slovenije. Na ta način je oddelčna knjižnica prevzela vso skrb za zameno osrednje slovenske geografske revije in s tem pridobila pravico do revij, pridobljenih na ta način (Šifrer in Turk 1998). Knjižnica je še naprej strokovno urejala druš-tveno knjižnico. Leta 1999 (sklep 7. seje IO ZGDS z dne 21. 1. 1999) je Zveza geografskih društev Slovenije knjižnico predala v last geografski knjižnici.

\subsection{Revije}

Pomemben del fonda knjižnice Oddelka za geografijo predstavlja tudi zaloga letnikov revij s področja geografije in geografiji sorodnih ved. Revije predstavljajo neprecenljivo vrednost tako za našo knjižnico kot tudi za našo stroko, saj se preko člankov, objavljenih v revijah, najhitreje pride do rezultatov geografskega znanstvenoraziskovalnega dela in do informacij o znanstvenem in strokovnem dogajanju na področju geografije. V knjižnici se trudimo, da z naslovi revij pokrivamo različna geografska področja kakor tudi, da imamo čim več revij, ki jih prejemamo iz različnih krajev Slovenije, Evrope in sveta. V letu 2008 smo tekoče prejemali 296 naslovov revij.

Nekaj revij, ki jih je prejemalo Geografsko društvo Slovenije, knjižnica še vedno tekoče prejema - torej hranimo zaloge letnikov kakor tudi vse novejše letnike po letu 1969 do danes 
(npr. za Geographische Zeitschrift hranimo zalogo od leta 1895, za Geographical Journal pa od leta 1921).

Knjižnica pridobiva revije na tri načine: kot dar, z zameno in z nakupom. Revije, ki prihajajo kot dar, podarjajo založniki ali geografska društva. Dar še vedno predstavlja določen delež v nabavi revij, največji delež pa predstavlja zamena. Z zameno skrbimo za popularizacijo slovenske geografije po svetu. Poteka tako, da pošiljamo naše revije Dela, Geografski vestnik, Geografija v šoli in Geografski obzornik, prejemamo pa kakovostne geografske in njim sorodne revije iz nekaterih evropskih držav, nekatere tudi z ostalih kontinentov (izjema je Afrika). Z zameno dobimo kar dve tretjini vseh revij. Najprej je zamena potekala pod okriljem Geografskega društva Slovenije, ki je pošiljalo društveno glasilo Geografski vestnik na različne naslove v takratni Jugoslaviji, v tujino in po Sloveniji. Že leta 1926 so pošiljali Geografski vestnik na 31 naslovov, leta 1930 na 92 naslovov in leta 1934 na 119 naslovov.

Slika 3: Zamena publikacije Dela

Figure 3: Exchange for the publication Dela

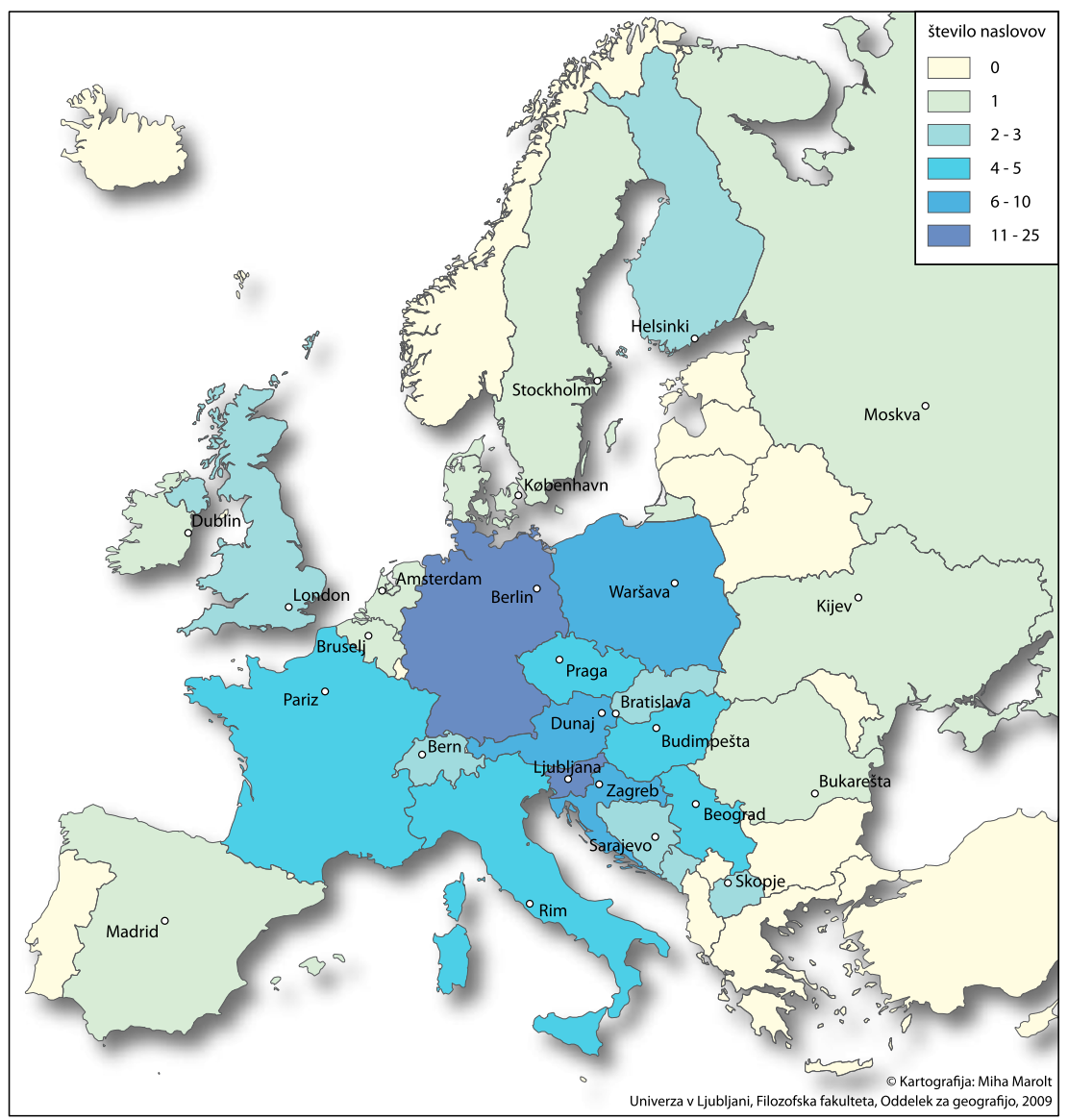


Ko je pričela izhajati oddelčna revija Dela, se je tudi ta vključila v zameno. Leta 2008 smo poslali Dela na 130 naslovov, Geografski vestnik na 127 naslovov, Geografski obzornik na 16 naslovov, Geografijo v šoli na 4 naslove. Z letom 2009 smo v zameno vključili tudi oddelčno knjižno zbirko GeograFF.

Knjižnica Oddelka za geografijo kupuje (2008) 34 naslovov tujih revij in 23 naslovov slovenskih revij. Med njimi je nekaj takih, ki se uvrščajo na vrh seznamov revij glede na faktorje vpliva za posamezne stroke, npr.: Transactions of the Institute of British Geographers, Economic geography, Progress in human geography, Progress in physical geography, Area, Urban geography itd. Veliko naročenih revij je danes že na spletu. Imajo svoje domače strani ali pa so dostopne preko servisov, kjer je večji nabor revij različnih strok in je možno iskanje člankov v polnem besedilu.

\subsection{Kartografska zbirka}

Študija geografije in znanstvenoraziskovalnega dela si ne moremo predstavljati brez kartografskega gradiva. To je javno dostopno v kartografski zbirki, ki obsega najrazličnejše karte od druge polovice 19. st. dalje, največ kart slovenskega ozemlja. Najstarejše so avstroogrske in italijanske topografske karte različnih meril. Sledijo različne izdaje topografskih kart Vojnogeografskega inštituta iz Beograda za ozemlje Jugoslavije ter topografske karte za ozemlje Slovenije, ki sta jih izdala Geodetski zavod in Geodetska uprava RS. V zbirki je tudi več kot 2400 listov temeljnih topografskih načrtov Slovenije v merilih $1: 5000$ in $1: 10.000$. Med najbolj pogosto uporabljenimi so tematske karte tako za Slovenijo kot tudi za druge države in celine (avtokarte, načrti mest, turistične, planinske, občinske, geološke, upravne in druge karte). Število kart je nenehno naraščalo, konec leta 2008 je kartografska zbirka štela že 38.402 kart in 415 atlasov.

Slika 4: Kartografska zbirka (foto: M. Rebolj)

Figure 4: The map room (photo: M. Rebolj)

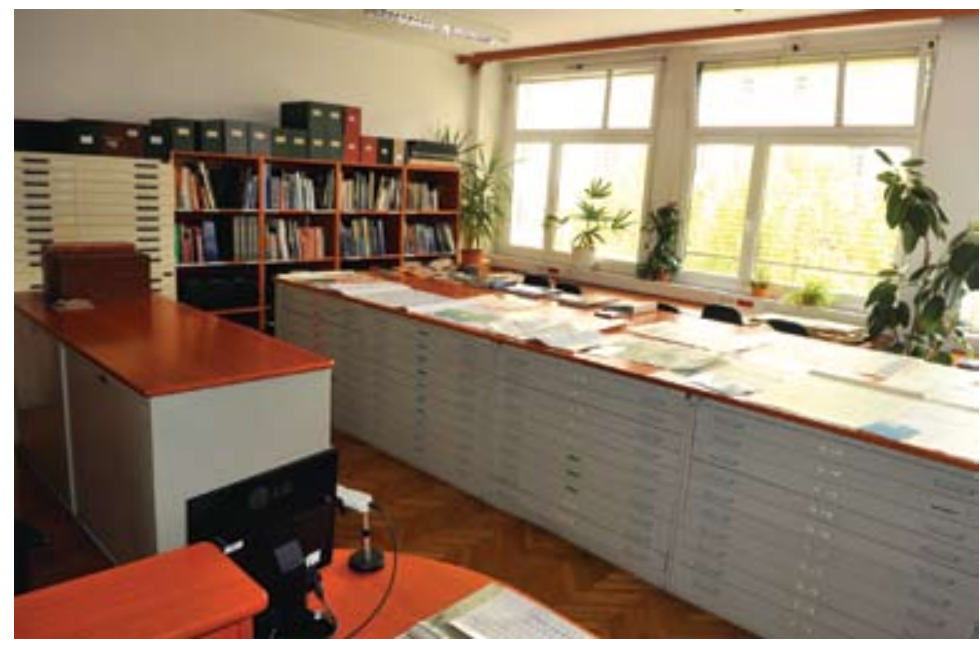


Danes kartografska zbirka tako po velikosti fonda kot po odprtosti presega marsikatero manjšo visokošolsko knjižnico. Srečujemo pa se s pomanjkanjem prostora in s problemom katalogizacije starejšega gradiva, zaradi pomanjkanja časa pa tudi zaradi nedorečenih pravil za vnos topografskih kart v sistem COBISS. Razvoj kartografske zbirke vidimo v digitalizaciji starejšega gradiva in v posredovanju informacij o dostopnosti kartografskega gradiva v elektronski obliki.

\section{KATALOGI}

V geografski knjižnici je bila od vsega začetka delovanja dobro razvita informacijska dejavnost. Strokovno podkovani bibliotekarji in sistematično urejeni katalogi so nudili obiskovalcem vse potrebne informacije. Listkovni katalogi so se dopolnjevali do leta 2000. Poleg osnovnega abecednega imenskega kataloga (kataložni listki so razvrščeni po avtorju ali na-slovu) je knjižnica gradila tudi sistematski katalog. Potrebe obiskovalcev so narekovale izdelavo kataloga, ki upošteva regionalni princip (razvrščanje listkov po posameznih državah in manjših regionalnih enotah) ter sistematiko geografije (gesla iz fizične in družbene geografije itd.). Izdeloval se je regionalni katalog sveta, stvarni in regionalni katalog Slovenije in Jugoslavije, stvarni in regionalni katalog diplomskih del, naslovni in stvarni katalog revij.

Kataložni listki so vsebovali podatke o knjigah, kartah, kongresnih in drugih zbornikih, serijskih publikacijah in drugem knjižnem gradivu. Bibliotekarji so načrtno in sistematično pregledovali prispele domače in tuje revije ter zbornike in iz njih katalogizirali strokovno in metodološko pomembne članke. Gradivo se je obdelovalo po mednarodnih standardih za opis knjižnega gradiva ISBD (M) in neknjižnega gradiva ISBD (CM). Zaradi velikega števila katalogiziranih enot in razvoja stroke se je število gesel povečalo na okoli 280.

Leta 1987 je knjižnica pričela izdelovati računalniški katalog. Na prvem računalniku Atari je nastajala lokalna bibliografska baza v računalniškem programu Steve. Modernizacija se je nadaljevala in leta 1990 je knjižnica pričela sodelovati z Računalniškim centrom Univerze v Ljubljani. V programskem paketu Trip je izdelovala računalniški katalog knjig GEOFFM in člankov GEOFFC. Celotna baza GEOFF je vsebovala 13.500 zapisov. Leta 1997 je knjižnica prenehala $\mathrm{z}$ vnosom v GEOFF. V lokalno bazo sistema COBISS se je preneslo le del člankov za potrebe bibliografije raziskovalcev Filozofske fakultete.

Z letom 1993 je knjižnica postala aktivna članica sistema COBISS. V katalog se je pričelo katalogizirati knjižno in neknjižno gradivo ter za geografe pomembne in zanimive članke iz slovenskih revij. Do danes so bibliotekarke geografske knjižnice kreirale 20.683 in prevzele 13.963 zapisov. Velik doprinos h katalogizaciji so zapisi za kartografsko gradivo, doslej je bilo izdelanih 4.074 zapisov za karte.

$Z$ računalniško obdelavo gradiva je seznam gesel za listkovni katalog postal nezadosten, zato smo leta 2002 izdali Vsebinske predmetne oznake - Geografija, ki jih je verificiral Oddelek za vsebinsko obdelavo v Narodni in univerziteni knjižnici v Ljubljani (Knez Račič, Miklič Cvek in Turk 2002). Geslovnik je bil dopolnjen z angleškimi prevodi gesel ter z vrstilci UDK. Namenjen je klasifikaciji gradiva v vzajemnem katalogu COBIB in podatkovni zbirki Katalog seminarskih nalog Oddelka za geografijo ter uporabnikom pri lažjem iskanju gradiva. 
Katalog seminarskih nalog obsega seminarske naloge študentov geografije na Oddelku za geografijo Filozofske fakultete. V programu Eva tekoče katalogiziramo vse naloge, v katalogu pa se lahko iščejo po ključnih besedah, avtorju, mentorju, vsebinskih in regionalnih predmetnih oznakah ter letu izdelave.

V septembru 2005 se je Oddelek za geografijo Filozofske fakultete pridružil tistim fakultetam, ki študentom, zaposlenim in šiši javnosti nudijo dostop do digitalne zbirke, kjer so polna besedila diplomskih del, magistrskih del in doktorskih disertacij (http://geo.ff.unilj.si/pisnadela).

Slika 5: Vstopna stran digitalne zbirke diplomskih del, magistrskih del in doktorskih disertacij Oddelka za geografijo

Figure 5: The portal to the digital collection of diploma works, master's theses and doctoral dissertations of the Department of Geography

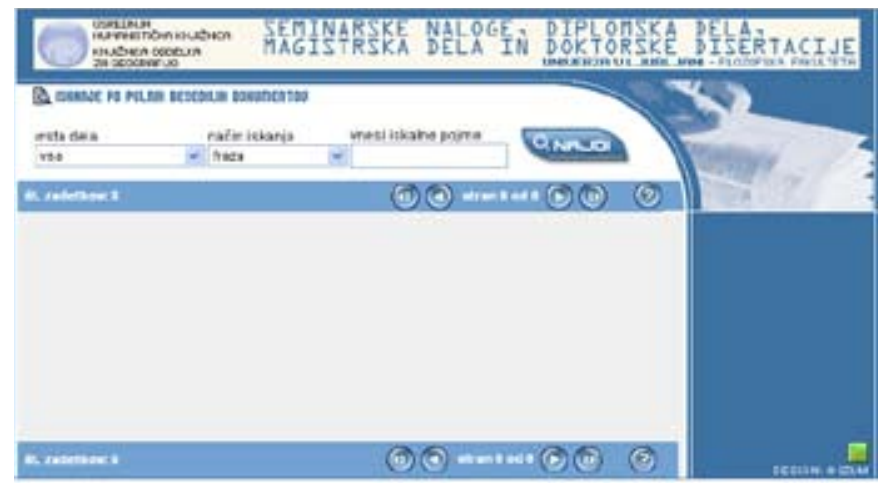

Za brskanje po zbirki je nameščen IZUM-ov vmesnik, ki išče dokumente po besedah v tekstu, zadetke pa razporedi glede na stopnjo ustreznosti iskalni zahtevi. Digitalizirana besedila so povezana s sistemom COBISS. Do konca leta 2008 so bila digitalizirana že 303 dela.

Za zbirko skrbi in jo dopolnjuje knjižnica. Študenti v skladu z diplomskim redom oddajo v knjižnico poleg tiskanega tudi izvod svojega dela v digitalni obliki. Bibliotekarke v knjižnici dela najprej katalogizirajo v vzajemnem katalogu COBIB, nato izvedejo postopek objave v digitalni zbirki. Za digitalno zbirko smo se odločili, ker smo želeli omogočiti lažji dostop do gradiva, ki ga je sicer možno pregledovati samo v knjižnični čitalnici.

Tako obiskovalci knjižnice kot statistični podatki uporabe strani potrjujejo, da je bila namestitev zbirke pravilna odločitev.

\section{UPORABNIKI KNJIŽNICE}

Ob ustanovitvi je knjižnica služila študentom in profesorjem geografije, zaradi svojega gradiva pa je postajala zanimiva tudi za druge obiskovalce. Danes je javno dostopna visokošolska knjižnica. Obiskovalci so študenti geografije in drugih strok, zaposleni na univerzi 
in drugi, ki jih zanima geografija kot znanstvena veda ali kot knjižnica z dobro zbirko popotniške literature in kartografskega gradiva.

Slika 6: Uporabniki geografske knjižnice

Figure 6: Visitors to Geographical Library

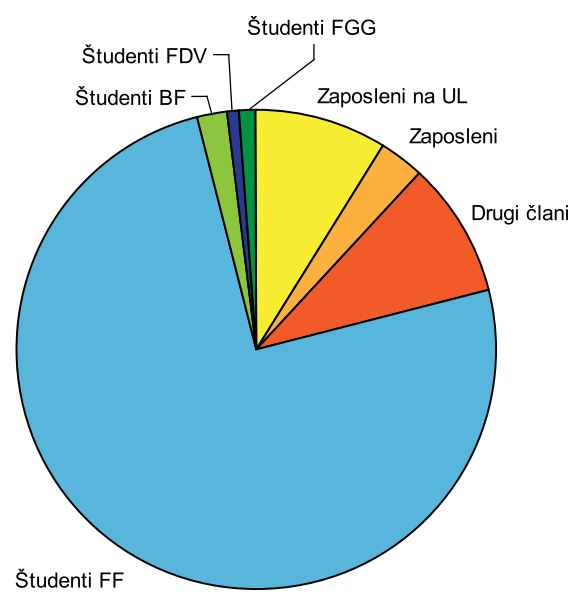

Slika 7: Obisk v knjižnici in kartografski zbirki

Figure 7: Number of visitors to the library and the map room

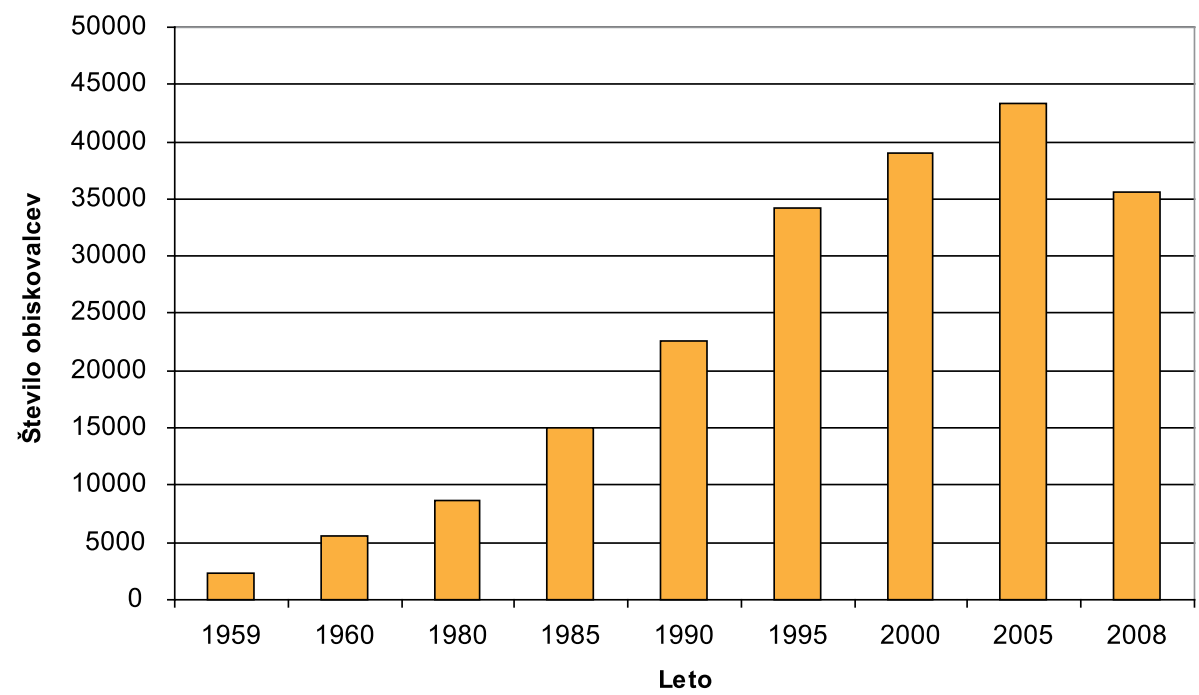

Vir/Source: Poročila o delu visokošolske knjižnice za leta 1959, 1960, 1980, 1985, 1990, 1995, 2000, 2005, 2008 
Knjižnica ima v povprečju letno okoli 1800 aktivnih članov. Po podatkih iz leta 2008 so največja skupina obiskovalcev knjižnice študenti, ki predstavljajo 79 \% aktivnih članov. Iz vrst sodelavcev univerze je $9 \%$ članov, zaposlenih je $3 \%$ in drugih članov (dijaki, nezaposleni, tuji državljani) $9 \%$. Tri četrtine študentov prihajajo iz matične ustanove, prevladujejo študenti geografije. Od ostalih fakultet so najpogostejši obiskovalci z Biotehniške fakultete, Fakultete za družbene vede, Fakultete za gradbeništvo in geodezijo in drugih.

V knjižnici smo vsa leta beležili naraščanje števila obiskovalcev in izposojenega gradiva, a zadnja leta obisk in izposoja stagnirata. Vzrok za to je potrebno iskati v prodoru sodobnih medijev - uporabi elektronskih informacijskih virov. Leta 2008 si je 35.545 obiskovalcev izposodilo 58.941 enot knjižničnega gradiva.

Geografska knjižnica je s Katalogom pisnih del, digitalno zbirko diplomskih del, magistrskih del in doktorskih disertacij omogočila oddaljen dostop do teh del v polnem besedilu. V letu 2008 smo zabeležili 3600 dostopov do zbirke in 14.300 pregledanih strani. Največ obiskovalcev strani, več kot 90 \%, prihaja iz Slovenije, sledijo Finska, Hrvaška, Portugalska, Francija, Srbija, Češka, Španija, Nemčija in Avstrija.

\section{Slika 8: Izposoja v knjižici in kartografski zbirki}

Figure 8: Materials borrowed from the library and the map room

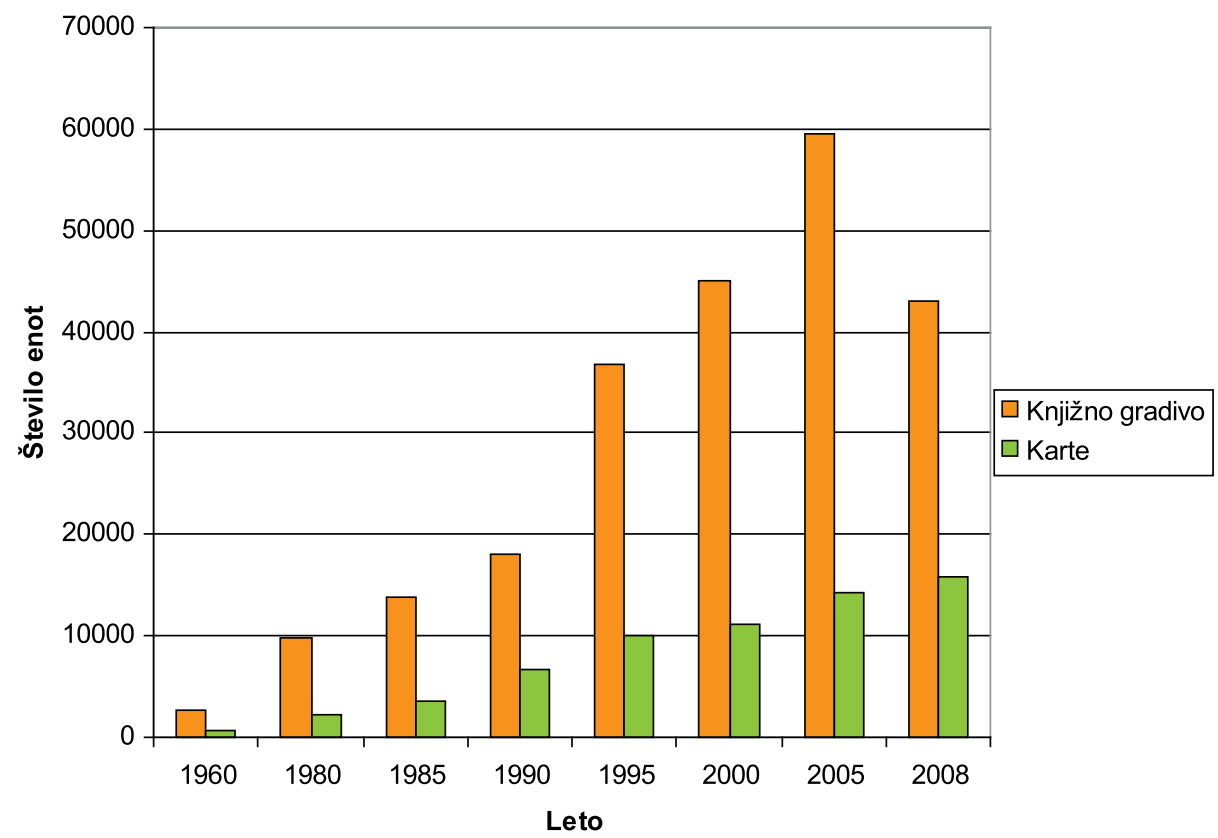

Vir/Source: Poročila o delu visokošolske knjižnice za leta 1960, 1980, 1985, 1990, 1995, 2000, 2005, 2008 


\section{DEJAVNOSTI KNJIŽNICE}

\section{I. Izobraževanje}

Knjižnica si prizadeva za učinkovito rabo informacij, saj tako izpolnjuje naloge izobraževanja in informacijskega opismenjevanja. Namen instrukcij je predvsem boljša in učinkovitejša uporaba knjižnice in informacijskih virov.

Knjižnica že od študijskega leta 1978/1979 izvaja individualno in skupinsko bibliopedagoško delo. Ker gradivo ni v prostem pristopu, je izobraževanje vključevalo predstavitev knjižnice z obveznimi praktičnimi vajami za študente 1. letnikov, da so se naučili uporabljati predmetni (vsebinski) in abecedni imenski katalog. Po prehodu na sistem COBISS so se v knjižnici uvedli tečaji, ki so se izvajali enkrat tedensko. V študijskem letu 1998/1999 se je izobraževanje za uporabo elektronskih virov vključilo v obvezne študijske vsebine pri predmetu Uvod v geografijo. Za študente višjih letnikov so se izvajali enkrat tedensko dveurni tečaji, prilagojeni njihovim specifičnim potrebam (Dolgan Petrič 1999).

Študenti, ki se sedaj vpisujejo na fakulteto, večinoma že poznajo sistem COBISS in so že bolj ali manj vešči v iskanju gradiva po vzajemnem in lokalnih katalogih. Tudi iskanje raznih informacij ali vsebin prek interneta jim ne predstavlja velike težave. Študenti pri vajah pri predmetu Uvod v geografijo poslušajo nekatere vsebine o iskanju in uporabi virov in literature v geografiji. Še vedno se izvajajo ogledi knjižnice s predstavitvijo njene dejavnosti. Pri predstavitvi študente povabimo na računalniške instrukcije iz uporabe sistema COBISS zaradi lažjega in predvsem hitrejšega iskanja knjižničnega gradiva. Za potrebe študija študente geografije usmerimo k uporabi informacijskih virov, katerih povezave imamo objavljene na domači strani knjižnice. Študenti se v različnem številu udeležujejo instrukcij, predvsem je število udeležencev odvisno od njihovega predhodnega znanja, lastne zainteresiranosti in pisne vaje, ki jo morajo opraviti pri predmetu Uvod v geografijo in ki vključuje rezultate iskanja gradiva na neko konkretno iskalno zahtevo.

Od študijskega leta 2008/2009 ob povečanem obisku študentov s tujih univerz v okviru različnih mednarodnih programov (npr. Erasmus) tudi za njih izvajamo oglede knjižnice in jim nudimo računalniške instrukcije. Za lažje razumevanje pravil in uporabo knjižnice imamo pripravljen Kažipot po knjižnici tudi v angleškem jeziku.

\subsection{Informacijski viri}

V informacijski družbi je pomembno hitro pridobivanje ažurnih informacij. To omogoča predvsem uporaba računalnikov in interneta, kar pomeni, da morajo biti informacije v elektronski obliki. Zahtevam moderne informacijske družbe se prilagajajo tudi knjižnice. Za uporabnike geografske knjižnice smo izbrali nekaj informacijskih elektronskih virov, do katerih lahko dostopajo prek spletne strani knjižnice pod razdelkom Informacijski viri.

Informacijski viri so razvrščeni v več skupin: e-revije, e-knjige, baze povzetkov, bibliografske baze, citatni indeksi, e-priročniki, iskalniki virov na internetu in podatki.

Pri e-revijah so navedene različne baze elektronskih revij, ki nudijo iskanje in branje člankov v polnem besedilu, pri e-knjigah so zbrani informacijski viri, ki omogočajo branje knjig v elektronski obliki, pri e-priročnikih je na voljo referenčna literatura, kot so slovarji 
in enciklopedije. V bazah povzetkov je mogoče iskati strokovno literaturo, vendar so na voljo samo povzetki. Bibliografske baze omogočajo samo iskanje strokovne literature, citatni indeksi obsegajo bibliografske podatke z izvlečki in citiranimi referencami o člankih ter omogočajo tudi iskanje o citiranosti določenega avtorja. Izbrani so še določeni iskalniki strokovnih informacijskih virov na internetu. Na voljo so tudi povezave na različne statistične in druge podatke, ki jih študenti geografije uporabljajo pri študiju. Viri so skupaj z opisi urejeni tudi po abecednem vrstnem redu. Število virov in načini dostopanja do njih se z leti nenehno spreminjajo.

Do omenjenih virov je možno dostopati na različne načine. Nekateri viri so prosto dostopni na internetu, drugi samo preko računalniške mreže Univerze v Ljubljani, tretje pa je možno uporabljati tudi prek t.i. oddaljenega dostopa. Oddaljeni dostop je namenjen predvsem študentom in zaposlenim na Univerzi v Ljubljani, zanj pa potrebujejo geslo, ki ga dobijo v knjižnici. Za pregledovanje informacijskih elektronskih virov se uporabljajo računalniki na Filozofski fakulteti. V knjižnici so trije računalniki, ki imajo dostop do interneta in so priključeni na računalniško mrežo Univerze v Ljubljani.

\subsection{Oddelčna publikacija Dela v mednarodnih bazah podatkov}

V knjižnici skrbimo, da je oddelčna revija Dela indeksirana v mednarodnih bazah podatkov. To je pomembno tako za samo kategorizacijo revije kot tudi za njeno pojavnost in $\mathrm{s}$ tem posledično uporabnost in branost v mednarodnih bibliografskih bazah. Dela so indeksirana $\mathrm{v}$ naslednjih mednarodnih bazah podatkov: GEOBASE, SCOPUS, GEOBIB, Russian Academy of Science Bibliography, FRANCIS, GeoRef, IBSS, DOAJ in v še posebej pomembni bazi, Current geographical publications, ki jo priznava Agencija za raziskovalno dejavnost Republike Slovenije pri vrednotenju znanstvene uspešnosti raziskovalcev. Revija je tudi vključena v tri sezname elektronskih revij: Ulrich's periodicals directory, Elektronische Zeitschriftenbibliothek in dLib.si.

Za pojavnost revije Dela v teh bazah je potrebno tekoče pošiljati tiskane izvode novih številk, omogočen mora biti dostop do elektronske verzije, skrbeti je potrebno za ažurnost podatkov o reviji (npr. spremembi urednika), za bazi FRANCIS in DOAJ pa je potrebno vnašati v posebnem programu bibliografske podatke o novih objavljenih člankih.

\subsection{Bilten novosti}

V knjižnici že vse od študijskega leta 1967/1968 izhaja Bilten novosti geografske knjižnice. V tiskani obliki je pričel izhajati z naslovom Bilten - seznam novodošle literature. V njem so bile po abecedi razvrščene knjižnične novosti. Kasneje je bilo knjižnično gradivo razvrščeno po vrstilcih UDK. Od januarja 2000 je Bilten novosti dostopen na spletni strani knjižnice in s povezavo na vzajemni katalog COBISS/OPAC. Izhaja šestkrat letno.

\subsection{Bibliografije}

Za zaposlene na Oddelku za geografijo v sodelovanju z avtorji sproti vodimo bibliografije. 
V osemdesetih letih je v okviru Znanstvenega inštituta Filozofske fakultete bibliografija izhajala v posebni izdaji Novic Filozofske fakultete z naslovom Katalog ob razstavi publikacij in predstavitvi izsledkov znanstvenoraziskovalnega dela. Bibliografija Znanstvenega inštituta Filozofske fakultete od leta 2000 izhaja v elektronski obliki na spletni strani Osrednje humanistične knjižnice.

Vodenje bibliografij sodelavcev Oddelka z ustrezno tipologijo dokumentov v sistemu COBISS je postalo zelo pomembno zaradi spremljanja raziskovalne in strokovne uspešnosti raziskovalcev v Informacijskem sistemu o raziskovalni dejavnosti v Sloveniji (SICRIS). Za področje humanistike, kamor se po klasifikaciji Agencije za raziskovalno dejavnost Republike Slovenije uvršča geografija, ni citiranosti bibliografskih zapisov v Web of Science, ki bi bili povezani z zapisi v sistemu COBISS. Zato v knjižnici tekoče spremljamo objave v publikacijah in izdelujemo sezname citatov za posamezne raziskovalce.

V knjižnici Oddelka za geografijo vodimo tudi bibliografijo slovenskih geografov. Inštitut za geografijo Univerze v Ljubljani je v letih 1960-1992 v obliki serijske publikacije izdajal Geografsko bibliografijo Slovenije. Z začetkom vzajemne katalogizacije gradiva v sistemu COBISS smo se v knjižnici kot osrednji knjižnici za področje geografije odločili, da nadaljujemo s spremljanjem objav slovenskih geografov v knjižnici dostopnih virov. Zapise označujemo z ustrezno oznako. V obdobju 1993-2008 smo kreirali oziroma prevzeli 9652 bibliografskih zapisov.

V knjižnici sestavljamo tudi tematske bibliografije in osebne bibliografije ob življenjskih jubilejih sodelavcev Oddelka za geografijo.

\section{Izbor bibliografij, izdelanih v knjižnici Oddelka za geografijo:}

Šifrer, T. 1985: Bibliografija del o industrijski geografiji SFR Jugoslavije = Bibliografija radova o industrijskoj geografiji SFR Jugoslavije = Bibliography of publications on Yugoslav industrial geography 1945-1978. Oddelek za geografijo in Znanstveni inštitut Filozofske fakultete, 268 str. (Industrializacija Jugoslavije 5). Ljubljana.

Turk, J. 1985: Bibliografija Geografskega obzornika I (1954) - XXXI (1984). Geografski obzornik 32, 2, 133 str. Ljubljana.

Turk, J. 1985: Bibliografija v tujini objavljenih del članov Oddelka za geografijo=Bibliography of articles published abroad by the members of Department of geography 1945-1984. Dela 1, 63 str. Ljubljana.

Dolgan Petrič, M. 1994: Vloga slovenske geografije v mednarodni promociji Slovenije. Bibliografija v tujini objavljenih del slovenskih geografov 1989-1994. Oddelek za geografijo Filozofske fakultete in Inštitut za geografijo Univerze v Ljubljani, 27 str. Ljubljana.

Turk, J. 1995: Bibliografija Geografskega vestnika 1925-1995: letnik 1-66. Geografski vestnik 67, str. 215-263. Ljubljana.

Dolgan Petrič, M., Knez Račič, I., Turk, J. 1997: Bibliografija prof. dr. Vladimirja Klemenčiča za obdobje 1952-1996. Dela 12, str. 275-303. Ljubljana.

Bibliografija Geografskega vestnika 1925-1998: letnik 1-70. Zveza geografskih društev Slovenije, 133 str. Ljubljana. 
Dolgan Petrič, M. 2000: Alpe - bibliografija objavljenih del v obdobju 1980-1999. V: Trajnostni razvoj v slovenskem alpskem svetu. Oddelek za geografijo, Filozofska fakulteta Univerze v Ljubljani, str. 3-47. Ljubljana 2000.

Dolgan Petrič, M., Knez Račič, I., Mlinar Strgar, M. 2000: Pomembnejša bibliografija akademika Igorja Vrišerja. Geografski vestnik 72, 1, str. 121-130. Ljubljana.

Turk, J. 2002: Geografska bibliografija. V: I. Vrišer: Uvod v geografijo.Oddelek za geografijo, Filozofska fakulteta Univerze v Ljubljani, str. 309-376. Ljubljana.

Knez Račič, I., Mlinar Strgar, M., Turk, J. 2003: Bibliografija akademika prof. dr. Ivana Gamsa. Dela 20, str. 147-173. Ljubljana.

Knez Račič, I., Turk, J. 2003: Mednarodno sodelovanje sodelavcev Oddelka za geografijo. Bibliografija v tujini objavljenih del 2000-2002. Dela 19, str. 219-223. Ljubljana.

Knez Račič, I., Mlinar Strgar, M., Turk, J. 2005: Bibliografija akademika Ivana Gamsa = Bibliography of academician Ivan Gams. Slovenska akademija znanosti in umetnosti (Bibliografije akademikov 1). Ljubljana. Internet: http://www.sazu.si/gams.pdf

Knez Račič, I., Lampič, B. 2007: Predstavitev znanstvenega, strokovnega in pedagoškega dela profesorja Darka Radinje. Dela 28, str. 400-412. Ljubljana.

\section{SKLEP}

Dobro strokovno delo v knjižnici Oddelka za geografijo na geografskem in bibliotekarskem področju dokazujejo priznanja tako knjižnici kot zaposlenim. Leta 2002 je Zveza geografskih društev Slovenije podelila knjižnici zlato plaketo za prispevek v izobraževanju in seznanjanju geografov z novostmi in idejami geografske misli po svetu.

Leta 2002 in 2004 sta bili izvedeni anketi med uporabniki knjižnice z namenom, ugotoviti pričakovanja in zadovoljstvo uporabnikov s storitvami knjižnice. Anketi sta pokazali podobne rezultate. Obiskovalci so najbolj zadovoljni z osebjem knjižnice, knjižničnimi storitvami in knjižnično zbirko, največ sprememb pa si želijo pri ponudbi prostora in opremi knjižnice: izboljšanje informacijske opremljenosti knjižnice, povečanje čitalnice in s tem več čitalniških mest, prost pristop do gradiva ipd. (Turk 2002; Povšič 2005).

V skladu z vizijo razvoja, ki smo si jo zadali že v preteklosti, knjižnica kljub pomanjkanju prostora, opreme, osebja in sredstev načrtuje, da bo postala osrednje geografsko informacijsko središče, ki bo s svojimi kakovostnimi storitvami podpiralo študijsko in raziskovalno delo, pripomoglo k ustvarjanju novega znanja in prenosu znanja iz bogastva knjižnih zbirk.

\section{Viri in literatura}

Dolgan Petrič, M. 1999: Informacijska pismenost in načrtovanje izobraževanja v visokošolskih knjižnicah. V: Pomen in delo visokošolskih knjižnic, str. 60-75. Ljubljana.

Gavazzi, A. 1922: Geografski institut sveučilišta u Ljubljani. Nastavni vjesnik 30, str. 536539. Zagreb.

Informacijskiviri.URL:http://www.ff.uni-lj.si/oddelki/geo/oddelek/knjiznica/informacijski_ viri.html (10.7.2009) 
Koler Povh, T., Božič, M. 2008: Gozdarska knjižnica ob svoji 60-letnici. Knjižnica 52, 2-3, str. 149-166. Ljubljana.

KnezRačič, I., Dolgan Petrič, M. 1997: Nekaj misli ob preureditvi kartografske zbirke Oddelka za geografijo Filozofske fakultete. Knjižničarske novice 7, 1, str. 14-15. Ljubljana.

Knez Račič, I., Miklič, L., Turk, J. 2002: Vsebinske predmetne oznake. Geografija. Oddelek za geografijo, Filozofska fakulteta. Ljubljana.

Knjižnica. URL: http://geo.ff.uni-lj.si/index.php?q=knjiznica (10.7.2009)

Miklič Cvek, L. 2008: Digitalna zbirka seminarskih, diplomskih, magistrskih in doktorskih del Oddelka za geografijo. Glasoffil 5, 14, str. 6. Ljubljana.

Petdeset let slovenske univerze v Ljubljani. 1919-1969. Univerza v Ljubljani. Ljubljana 1969.

Pivec Stele, M. 1933: Naše knjižnice. Ljubljana.

Poročilo o delu Filozofske fakultete Univerze v Ljubljani. Filozofska fakulteta. Ljubljana (od študijskega leta 1960/1961 do 2002/2003).

Poročilo o delu visokošolske knjižnice. Narodna in univerzitetna knjižnica. Ljubljana (od leta 1959 do 2008).

Povšič, U. 2005: Pričakovanja in zadovoljstvo uporabnikov s storitvami visokošolske knjižnice: primer knjižnice Oddelka za geografijo na Filozofski fakulteti. Diplomsko delo, Oddelek za bibliotekarstvo, informacijsko znanost in knjigarstvo, Filozofska fakulteta Univerze v Ljubljani. Ljubljana.

Seražin, H. 1996: Nastanek in razvoj knjižnic Filozofske fakultete v Ljubljani. Diplomsko delo. Oddelek za bibliotekarstvo, informacijsko znanost in knjigarstvo, Filozofska fakulteta Univerze v Ljubljani. Ljubljana.

Šifrer, T., Turk, J. 1989: O delu knjižnice Oddelka za geografijo Filozofske fakultete. Dela 6, 290-301. Ljubljana.

Turk, J. 2002: Knjižnica Oddelka za geografijo. Geomix 8, 2, str. 34-35. Ljubljana.

Vrišer, I. 2002: Uvod v geografijo. Oddelek za geografijo Filozofske fakultete. Ljubljana.

Zbornik Filozofske fakultete. 1919-1999. Filozofska fakulteta. Ljubljana 1999.

\section{NINETY YEARS OF GEOGRAPHICAL LIBRARY}

\section{Summary}

When the study of geography was established at the Institute of Geography at the University of Ljubljana in 1921, Geographical Library was also organized. The Institute of Geography was located in the 'Deželni dvorec' (former Provincial Mansion), the present building of the University of Ljubljana. The then students and assistants took care of modest library holdings which consisted of books, journals and maps, and kept increasing mainly thanks to gifts from different institutions and persons. The first professional librarian-geographer was employed in the 1950s. In 1961, new premises were built to house the Faculty of Arts, so the Department of Geography, together with its library, could also move to the new location, where the library holdings, the number of students and the faculty staff began to grow fast. Parallel to it, the number of librarians employed in the library increased, so that four librarians, all geographers, were employed in it by 2008 . 
The library holdings increase in different ways: through buying library material, receiving it as gifts from different institutions, exchanging materials, and acquiring material (master's theses, doctoral dissertations and diploma works) as deposit copy of the faculty. By the number of items (92.504 items in 2008) in its holdings the library of the Department of Geography is the second largest library at the Faculty of Arts. The library collections consist of monographs, serial publications, cartographic material and other non-book material. The material is mainly bought, presented as gifts from different institutions, or received in exchange for the publications Dela, Geografski vestnik, Geografski obzornik and Geografija v šoli. An important part of the library holdings consist of books that originally belonged to the Geographical Society of Slovenia and were handed over to the library in 1999.

Very interesting for the visitors is the collection of travel guides, both for Slovenia and different foreign countries and cities of Europe and the world, with free access, which is not the case with the rest of the library material.

Journals, covering different fields of geography and related sciences and coming from different parts of Europe and the world, represent another important part of the holdings. The library keeps the most important geographical journals, some of them dating back to the first volumes of the 19th century. Most of the journals are acquired through exchange, some through purchase, and some as gifts. In 2008 the library received volumes of 296 titles of journals.

It is not possible to study geography without cartographic material, therefore it is available in the map room. The cartographic collection consists of different kinds of maps (topographic maps, road maps, geological maps, hiking maps, tourist maps, etc.) and atlases. Most of them show Slovenian territory, and the oldest date back to the second half of the 19th century. A smaller part of the collection consists of cartographic material of different states and cities of Europe and the world. By the end of 2008 the cartographic collection contained 38.402 maps and 415 atlases.

From the very start the librarians, as well as different systematically arranged catalogues, provided the necessary information to the visitors to the library. Initially, classical card catalogues were made, while computer processing of the library materials began in the 1980s, and in 1993 the library became an active member of the COBISS bibliographic system. So, the making of classical card catalogues was eventually abandoned in 2000, since all bibliographical records are completely accessible via Internet, on COBISS/OPAC. The librarians catalogue books and cartographic material, serial publications and also articles, which is a unique feature of this geographical library. Separately a catalogue of 'seminar-works' is being made and, since 2005, the library has been offering the Internet access to the digital collection of fulllength texts of diploma works, master's theses and doctoral dissertations at the Department of Geography.

Geographical Library is a public high-school library and its visitors are mainly students of geography and other related sciences, employees of the University of Ljubljana and other people who are interested in geography.

An important service offered by the library is the training of its visitors, so that they can easily and quickly find the needed literature. Next to searching the catalogue, there is also the latest possibility of getting up-to-date geographical information from the Internet accessible 
information resources. The library of the Department of Geography is in charge of indexing the Department's publication Dela in the international databases, so that scientific efficiency of individual researchers, who publish their articles in this publication, can be properly evaluated.

Since 1967 the library has been publishing Bilten novosti, where all the library novelties are gathered and arranged according to the Universal Decimal Classification; initially, it was only published as a version printed on paper, and from 2000 onwards, it is available also in the electronic form.

Another important service of the library, being a high-school library, is to make different personal bibliographies of the members of the Department of Geography and - being a geographical library - to trace publications of Slovenian geographers.

In the future, the library will strive to become the central geographical information centre, which, thanks to its high quality services and modern technological equipment, is going to serve the study and the research process in geography and also meet the needs of other visitors who are interested in geography. 